\title{
Is COVID-19 Pandemic is out of control as compare to other Medical and Surgical Diseases, where Proven treatment is available for ill Patients
}

\author{
Ahsan Siddiqui, M.D, M.S.P.H (UK)* \\ Department of Quality Management \& Patient Safety, General Directorate of Health, Saudi Arabia
}

*Corresponding author: Ahsan Ali Siddiqui, Consultant Preventive Medicine and Epidemiologist, Department of Quality Management \& Patient Safety, General Directorate of Health, Riyadh Saudi Arabia

\section{ARTICLE INFO}

Received: 慧 July 20, 2020

Published: 幽 August 13, 2020

Citation: Ahsan Siddiqui. Is COVID-19 Pandemic is out of control as compare to other Medical and Surgical Diseases, where Proven treatment is available for ill Patients. Biomed J Sci \& Tech Res 29(3)2020. BJSTR. MS.ID.004816.

Keywords: COVID-19; Chloroquine; MERS; Morbidity; Remdesivir; SARS-CoV-2; Importing; Iran; Outbreaks; Spreading; Acute Respiratory Distress Syndrome; Antiviral; WHO list of Tuberculosis; Preventive Measures against Tuberculosis; Sleep Apnea; Hypertensive Patients; Duration of Hypertension; Neurological Symptoms; Hypertension; Blood Pressure Levels; Vitamin A deficiency; Maternal Mortality; Child Mortality

\author{
ABSTRACT
}

Background and Objective: The Aim of the article is to explore and present the COVID-19 successful prevention and treatment in current Pandemic. Also, to compare the previous treatment and prevention of other medical and surgical diseases with the failure in current COVID-19 management, Vaccine, and treatment availability.

Methods: The Author of this Article has done Literature Review, Comparison and Critical analysis of more than 25 Published Articles and other reviews. Author has chosen the Comparative Literature review as methodology for this research article. The purpose is to show that Randomly chosen articles are in favor of "Is COVID-19 Pandemic is out of control as compare to other Medical and Surgical Diseases, where Proven treatment is available for ill Patients". SPSS 19 software is used to show Diagrammatic presentation for the results and analysis. Initial part of the Article discusses and referenced the epidemiology and prevention of COVID-19 Pandemic. In the last part of the article the author discusses the other Medical/ surgical diseases and treatment and preventions.

Results: Author of this Article has used SPSS 19 Software to present the results. First SPSS Diagram shows that All selected 15 Articles favors "Is COVID-19 Pandemic is out of control as compare to other Medical and Surgical Diseases, where Proven treatment is available for ill Patients". The Second SPSS Diagram shows that 15 Articles agreed 100\% for "Is COVID-19 Pandemic is out of control as compare to other Medical and Surgical Diseases, where Proven treatment is available for ill Patients".

Conclusion: Although the Incidence, Distribution, Illness, and mortality due to COVID-19 Pandemic is reducing day by day as compare to peak in March 2020 in the EU, the UK and the USA. But the Head of CDC USA warn the WHO and US Government that COVID-19 Pandemic has the tendency to become deadly as same as Spanish flu Pandemic in 1918 where approximately 60 to 100 million people died. The governments of the 200 affected countries due to COVID-19 should understand the seriousness of the warnings and do the recommended preventions such as wearing Masks, washing hands with soap or sanitize it with Alcohol, social distancing and staying home as much as possible. In case of fever and shortness of breath take oxygen therapy, and paracetamol and ask the doctor for Antiviral, Plasma therapy and dexamethasone others as soon as possible.

\section{Introduction}

From the research objectives for SARS-CoV Carlyn Harris, et al. [1] and MERS-CoV ten themes in the literature were identified Clinical characterization prognosis diagnosis, clinical management, viral pathogenesis, epidemiological characterization, infection prevention and control/transmission, susceptibility, psychosocial, and etiology. For COVID19, some information on clinical presentation, diagnostic testing, and etiology is available but many clinical 
research gaps have yet to be filled. Based on a systematic review of other severe coronaviruses we summarize the state of clinical research for COVID-19 highlight the research gaps and provide recommendations for the implementation of standardized protocols. Data based on Carlyn Harris, et al. [1] internationally standardized protocols will inform clinical practice real-time. Latest Inventions in Science and Ahsan Ali Siddiqui, [2] Medical Technology are Blessing for all the Living being on this Planet Earth. From Human beings to Animals all are getting benefits to enjoy better health in twenty first century by modern treatment and surgical procedures for humans and Animals. The Human Doctor and Veterinary Doctor are getting modern medicines and technology to save the lives of their patients.

Latest Medical Inventions for example Nuclear Medicine/ Nuclear scan, CT Scan, MRI Scan, Laparoscope Machine, Imaging Machine, Ultrasound, X Rays, ICU Facility with Ventilators, Endoscopy Instruments, Others are helping the Doctors and Patients to provide and receive latest Treatment for the ill and sick. Although the Advancement in Medical Technology and Sciences still a lot of Research and hard work needed as still scientists Ahsan Ali Sid-

Table 1: Basic characteristics of included studies diqui, [2] could not find the appropriate and proven treatment and Vaccine of COVID-19. (Table 1) A total of 34 retrospective studies involving a total of 4121 patients with COVID-19 were included. The results of the meta-analysis showed that most patients presented bilateral lung involvement (73.8\%, 95\% confidence interval [CI]: 65.9\%-81.1\%) or multi lobar involvement (67.3\%, 95\% CI: $54.8 \%-78.7 \%$ ) and just little patients showed normal CT findings (8.4\%). Jieyun Zhu, et al. [3] As we all know that current Ahsan Ali Siddiqui, [4] Pandemic of COVID-19 novel corona virus is deadly and without vaccine and proven Treatment. More than quarter million people recently has died and more than four million people suffering from COVID-19 all over the world till May 2020. World health organization has issued the warning in December 2019 for the Novel corona virus in Wuhan China. Governments of the countries including most developed countries such as the USA, the UK and EU Countries act slowly with ignoring the facts about COVID-19 severity. The lesson learned from the Pandemic COVID-19 is that our health systems and health agencies do not have abilities to save their Ahsan Ali Siddiqui, [4] citizens and they have to work hard to improve their abilities to save their citizens. (Table 2) Jieyun Zhu, et al. [3].

\begin{tabular}{|c|c|c|c|c|c|c|c|c|}
\hline Study & $\begin{array}{l}\text { Publication } \\
\text { Date }\end{array}$ & $\begin{array}{l}\text { Region } \\
\text { (China) }\end{array}$ & $\begin{array}{l}\text { Sample Size } \\
\text { (n) }\end{array}$ & Study Population & Age, $\frac{a}{y}$ & Male (n) & Outcomes & $\begin{array}{l}\text { Quality } \\
\text { Score }\end{array}$ \\
\hline $\begin{array}{l}\text { Guan et } \\
\text { al. } 9\end{array}$ & Feb 28 & $\begin{array}{l}31 \text { Provinc- } \\
\text { es }\end{array}$ & 1099 & $\begin{array}{l}\text { COVID-19 patients in } 552 \text { hospitals in } 31 \\
\text { province/province-level municipalities }\end{array}$ & 47.0 & 640 & (1) (2) (3) & 6 \\
\hline $\begin{array}{l}\text { Cheng et } \\
\text { al. } 10\end{array}$ & Mar 12 & Hubei & 463 & $\begin{array}{l}\text { COVID-19 patients in wuhan Jinyintan } \\
\text { Hospital }\end{array}$ & $15-90$ & 244 & (1) (2) (3) (4) & 6 \\
\hline $\begin{array}{l}\text { Gong et } \\
\text { al. } 11\end{array}$ & Mar 9 & Chongqing & 225 & $\begin{array}{l}\text { COVID-19 patients in Chongqing Univer- } \\
\text { sity Three Gorges Hospital }\end{array}$ & $\begin{array}{l}46.35 \\
\pm 16.1\end{array}$ & 125 & (1) (2) (3) & 6 \\
\hline $\begin{array}{l}\text { Yuan et } \\
\text { al. } 12\end{array}$ & Mar 6 & Chongqing & 223 & $\begin{array}{l}\text { COVID-19 patients in Chongqing Public } \\
\text { Health Medical Center }\end{array}$ & $46.5 \pm 16.1$ & 105 & (1) (3) & 6 \\
\hline $\begin{array}{l}\text { Zhou et } \\
\text { al. } 13\end{array}$ & Mar 9 & Wuhan & 191 & $\begin{array}{l}\text { COVID-19 patients in Jinyintan Hospital } \\
\text { and Wuhan Pulmonary Hospital }\end{array}$ & $18-87$ & 119 & (1) (2) (3) & 7 \\
\hline $\begin{array}{l}\text { Yang et al. } \\
\quad 14\end{array}$ & Feb 26 & Wenzhou & 149 & $\begin{array}{l}\text { COVID-19 patients in three tertiary hos- } \\
\text { pitals of Wenzhou }\end{array}$ & $45.1 \pm 13.4$ & 81 & (1) (2) (3) (4) & 7 \\
\hline $\begin{array}{l}\text { Wu et al. } \\
\quad 15\end{array}$ & Mar 3 & Provinces & 130 & $\begin{array}{l}\text { COVID-19 patients in seven hospitals of } \\
\text { China }\end{array}$ & $25-80$ & 78 & (1) (2) (3) (4) & 7 \\
\hline $\begin{array}{l}\text { Bernheim } \\
\text { et al. } 16\end{array}$ & Feb 20 & $\begin{array}{l}4 \text { Prov- } \\
\text { inces }\end{array}$ & 121 & $\begin{array}{l}\text { COVID-19 patients in four centers in } \\
\text { China }\end{array}$ & $45(18-80)$ & 61 & (1) (3) (4) & 8 \\
\hline $\begin{array}{l}\text { Zhao et } \\
\text { al. } 17\end{array}$ & Feb 19 & Hubei & 101 & $\begin{array}{l}\text { COVID-19 patients in four cities in Hu- } \\
\text { nan, China }\end{array}$ & $17-75$ & 56 & (1) (2) (3) (4) & 6 \\
\hline $\begin{array}{l}\text { Chen et } \\
\text { al. } 18\end{array}$ & Feb 15 & Wuhan & 99 & $\begin{array}{l}\text { COVID-19 patients in Wuhan Jinyintan } \\
\text { Hospital }\end{array}$ & $55.5 \pm$ & 67 & (1) (3) & 6 \\
\hline $\begin{array}{l}\text { Xu et al. } \\
19\end{array}$ & Feb 28 & Guangzhou & 90 & $\begin{array}{l}\text { COVID-19 patients in Guangzhou Eighth } \\
\text { People's Hospital }\end{array}$ & $18-86$ & 39 & (1) (3) (4) & 6 \\
\hline Li et al. 20 & Feb 29 & $\begin{array}{l}\text { Chongq- } \\
\text { ing/Jinan }\end{array}$ & 83 & $\begin{array}{l}\text { COVID-19 patients in Chongqing/Jinan } \\
\text { provinces }\end{array}$ & 45.5 & 44 & (1) (2) (3) (4) & 8 \\
\hline $\begin{array}{l}\text { Shi et al. } \\
\quad 21\end{array}$ & Feb 24 & Wuhan & 81 & $\begin{array}{l}\text { COVID-19 patients in Wuhan Jinyintan } \\
\text { hospital or Union Hospital of Tongi } \\
\text { Medical College }\end{array}$ & 49.5 & 42 & (1) (2) (3) (4) & 7 \\
\hline $\begin{array}{l}\text { Wu et al. } \\
\quad 22\end{array}$ & Feb 21 & Chongqing & 80 & COVID-19 patients in Chongqing province & $44 \pm 11$ & 42 & (1) (2) (3) (4) & 7 \\
\hline
\end{tabular}




\begin{tabular}{|c|c|c|c|c|c|c|c|c|}
\hline $\begin{array}{l}\text { Wu et al. } \\
23\end{array}$ & Feb 29 & Jiangsu & 80 & $\begin{array}{l}\text { COVID-19 patients in the First- and Sec- } \\
\text { ond-People's Hospital of Yancheng City, } \\
\text { the Fifth People's Hospital of Wuxi }\end{array}$ & 46.1 & 39 & (1) & 8 \\
\hline $\begin{array}{l}\text { Fang et al. } \\
\quad 24\end{array}$ & Feb 25 & Anhui & 79 & $\begin{array}{l}\text { COVID-19 patients in Infection Hospital } \\
\text { of Anhui Provincial Hospital }\end{array}$ & $45.1 \pm 16.1$ & 45 & (1) & 5 \\
\hline $\begin{array}{l}\text { Chen et } \\
\text { al. } 25\end{array}$ & Mar 10 & Wuhan & 76 & $\begin{array}{c}\text { COVID-19 patients in Wuhan Puren } \\
\text { Hospital }\end{array}$ & $28-86$ & 40 & (1) (3) (4) & 6 \\
\hline $\begin{array}{l}\text { Ma et al. } \\
26\end{array}$ & Mar 10 & Anhui & 75 & $\begin{array}{l}\text { COVID-19 patients in } 4 \text { hospitals in Fuy- } \\
\text { ang city, Anhui province }\end{array}$ & $43.9 \pm 15.1$ & 46 & (1) (3) (4) & 7 \\
\hline $\begin{array}{l}\text { Pan et al. } \\
\quad 27\end{array}$ & Feb 6 & Wuhan & 63 & COVID-19 patients in Tongji hospital & $44.9 \pm 15.2$ & 33 & (1) (2) (3) & 6 \\
\hline $\begin{array}{l}\text { Zhou et } \\
\text { al. } 28\end{array}$ & Feb 19 & Wuhan & 62 & COVID-19 patients in Tongji hospital & $52.8 \pm 12.2$ & 39 & (1) (2) (3) (4) & 6 \\
\hline $\begin{array}{l}\text { Wang et } \\
\text { al. } 29\end{array}$ & Feb 25 & Zhejiang & 52 & $\begin{array}{l}\text { COVID-19 patients in the First Affiliated } \\
\text { Hospital, Zhejiang University School of } \\
\text { Medicine }\end{array}$ & $13-73$ & 29 & (1) (2) (3) (4) & 6 \\
\hline $\begin{array}{l}\text { Xu et al. } \\
\quad 30\end{array}$ & Feb 25 & $\begin{array}{l}\text { Beijing/ } \\
\text { Hebei }\end{array}$ & 50 & $\begin{array}{l}\text { COVID-19 patients in } 4 \text { hospitals in Bei- } \\
\text { jing/Hebei provinces }\end{array}$ & $43.9 \pm$ & 29 & (1) (3) (4) & 6 \\
\hline
\end{tabular}

Note: (1) Lesion Distribution; (2) Lesion Shapes; (3) Lesion Density; (4) Accompanying Signs

Abbreviations: COVID-19: Coronavirus Disease 2019; SD: Standard Deviation

Table 2: Meta-analysis of different CT imaging features in COVID-19 patients.

\begin{tabular}{|c|c|c|c|c|c|c|c|c|}
\hline & \multirow{2}{*}{ Outcomes } & \multirow{2}{*}{$\begin{array}{l}\text { No. Stud- } \\
\text { ies }\end{array}$} & \multirow{2}{*}{$\begin{array}{c}\text { No. Patients } \\
P\end{array}$} & \multicolumn{2}{|c|}{ Heterogeneity } & \multirow{2}{*}{$\begin{array}{c}\text { Model } \\
R(\mathbf{9 5 \%} \mathrm{CI})\end{array}$} & \multicolumn{2}{|c|}{ Meta-Analysis } \\
\hline & & & & $I^{2}$ & & & $P$ & \\
\hline \multirow{5}{*}{$\begin{array}{l}\text { Lesion Dis- } \\
\text { tribution }\end{array}$} & Single Lung Lesions & 22 & 1977 & $<001$ & $81.6 \%$ & Random & $.187(0.147,0.231)$ & $<001$ \\
\hline & Bilateral Lung Lesions & 28 & 2628 & $<001$ & $94.9 \%$ & Random & $.738(0.659,0.811)$ & $<001$ \\
\hline & Multilobar Lesions & 10 & 846 & $<001$ & $92.7 \%$ & Random & $.673(0.548,0.787)$ & $<001$ \\
\hline & Single Lobe Lesions & 9 & 629 & $<001$ & $79.6 \%$ & Random & $.149(0.092,0.217)$ & $<001$ \\
\hline & Normal CT Manifestation & 13 & 2195 & $<001$ & $93.3 \%$ & Random & $.084(0.042,0.139)$ & $<001$ \\
\hline \multirow{4}{*}{$\begin{array}{l}\text { Lesion } \\
\text { Shapes }\end{array}$} & Nodular & 8 & 739 & $<001$ & $96.3 \%$ & Random & $.205(0.068,0.391)$ & $<001$ \\
\hline & Patchy & 8 & 2009 & $<001$ & $94.1 \%$ & Random & $.403(0.298,0.514)$ & $<001$ \\
\hline & Cord-Like & 6 & 267 & $<001$ & $87.3 \%$ & Random & $.368(0.217,0.534)$ & $<001$ \\
\hline & Spider Web-Sign & 11 & 806 & $<001$ & $92.9 \%$ & Random & $.395(0.272,0.526)$ & $<001$ \\
\hline \multirow{4}{*}{$\begin{array}{l}\text { Lesion } \\
\text { Density }\end{array}$} & Ground-Glass Opacities & 26 & 3574 & $<001$ & $97.7 \%$ & Random & $.681(0.569,0.782)$ & $<001$ \\
\hline & Consolidation & 14 & 1637 & $<001$ & $95.4 \%$ & Random & $.320(0.215,0.434)$ & $<001$ \\
\hline & Air Bronchogram Sign & 15 & 1075 & $<001$ & $93.9 \%$ & Random & $.447(0.329,0.568)$ & $<001$ \\
\hline & Crazy-Paving Pattern & 4 & 264 & $<001$ & $95.8 \%$ & Random & $.356(0.113,0.648)$ & $<001$ \\
\hline \multirow{3}{*}{$\begin{array}{l}\text { Accompany- } \\
\text { ing Sign }\end{array}$} & Pleural Effusion & 17 & 1627 & 024 & $44.8 \%$ & Random & $.053(0.037,0.073)$ & $<001$ \\
\hline & Pleural Thickening & 9 & 1077 & $<001$ & $95.6 \%$ & Random & $.271(0.156,0.405)$ & $<001$ \\
\hline & Lymphadenopathy & 8 & 622 & $<001$ & $82.0 \%$ & Random & $.054(0.022,0.098)$ & $<001$ \\
\hline
\end{tabular}

Abbreviations: CI: Confidence Interval; COVID-19: Coronavirus Disease 2019; CT: Computed Tomography

Due to the Advancement in Medical Ahsan Ali Siddiqui, [5] Sciences and Medical Treatment, Inventions people are living longer and healthier than ever before. Nuclear Radiotherapy, Nuclear radiology, MRI Scan, CT Scan, X Rays, Ultrasound, Angioplasty and Angiography others made the diagnosing and treatment easier for the patients. Current COVID-19 Pandemic, MERS, SARS, EBOLA and other epidemics teaches us the lesson than as the world population grows, we need more research and technology to handle Pandemic such as COVID-19. More resources and advance technology are needed Ahsan Ali Siddiqui, [5,6] to battle diseases and training for medical staff is needed (Figure 1). Global Health and other organizations Ahsan Ali Siddiqui, [7] such as WHO, UNHCR, UN, UNESCO,
UNICEF did not act fast to Prevent and Control the COVID-19 Pandemic. Other Governments of the countries in the world act very slowly for the warnings given by WHO and other scientists. Later since November 2019 till now approximately 350,000 people have lost their lives due to COVID-19 and approximately 5 Million people are infected by this COVID-19 disease. Lessons should learn from COVID-19 Pandemic and it is not over yet as scientists predicts that COVID-19 is with us for next couple of years.

The vaccine of COVID-19 is under development and there is not exact Ahsan Ali Siddiqui, [7] treatment for COVID-19 by medical sciences till now (Figure 2). Approximately 10 Million Ahsan Ali Sid- 
diqui, [8] People are Infected with COVID-19 Corona virus and More than Half Million are Dead with current COVID-19 Pandemic till July 2020. Scientists are trying to manufacture COVID-19 Vaccine and Treatment as soon as possible to help the Mankind. In the current 21st century still people are dying with diseases without the treatment available as still we lack knowledge and research facilities to tackle the diseases. International health organizations for example WHO, UNICEF and UN should invest more on Medical research and pharmaceuticals to find the upcoming Epidemics or Pandemics and prepare their available Vaccines and Treatment. Without taking serious steps and proper design and management the Task for Medical research Ahsan Ali Siddiqui, [8,9] for disease Preventions could not be completed (Figure 3). Current Pandemic of COVID-19 novel corona virus Ahsan Ali Siddiqui, [10] has taught us a lesson that Global Health Agencies and Governments of the countries are not prepare for such Pandemic. The Governments has acted slowly or irresponsibly for the fight against COVID-19 Pandemic.

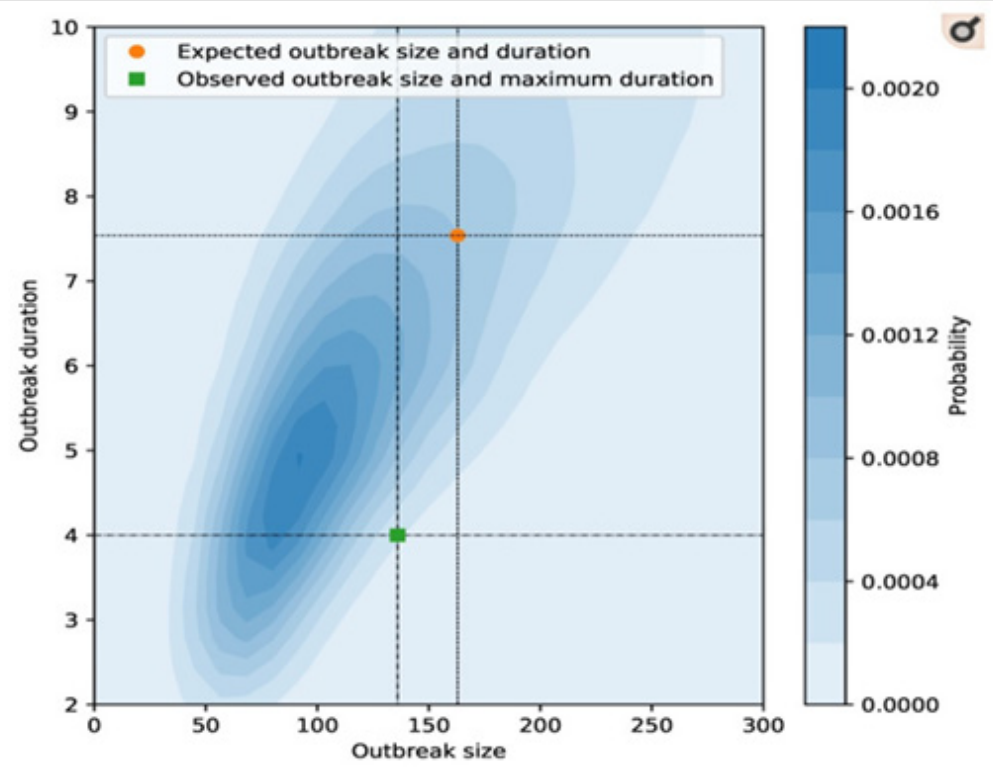

Figure 1: Simulated outbreak size and duration by assuming no control measures. Each simulation was started with 43 infections and based on reproductive number $\mathrm{R}=0.74$ and dispersion parameter $\mathrm{k}=0.14$, which were estimated from the data collected by 1 February 2020. The density and mean of duration and outbreak size were estimated based on 5000 Monte Carlo simulations. Yunjun Zhang, et al. [6].

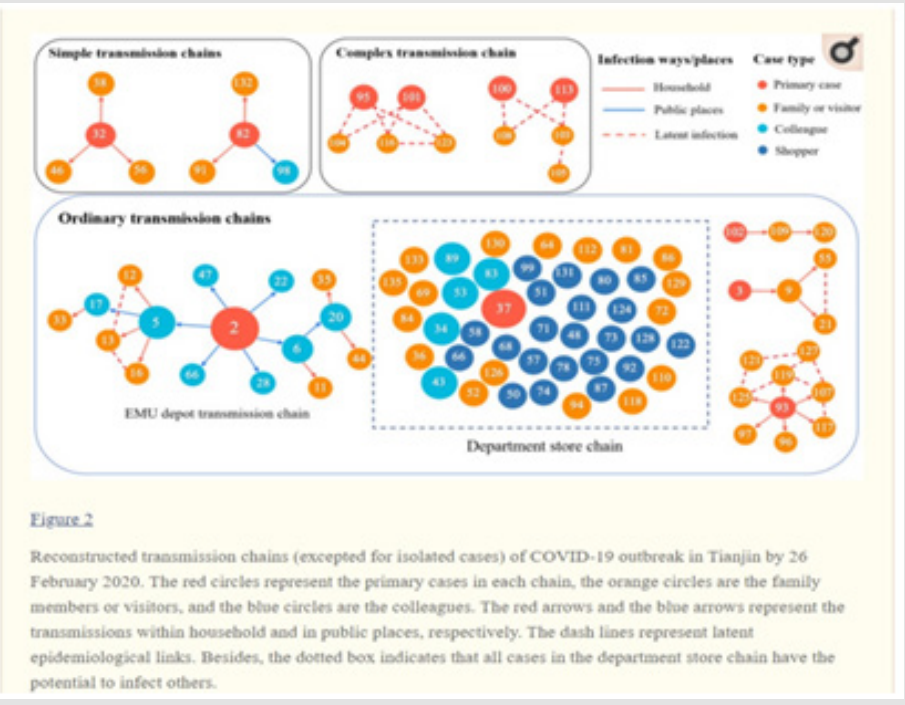

Figure 2: Yunjun Zhang, et al. [6].

Due to slow action to implement Preventive actions against COVID-19 approximately 300,000 people have lost their lives and more than four million people are Infected across the world. Better preparations are needed in the future to fight Ahsan Ali Siddiqui, [10] against such a cruel Pandemic disease (Figure 4). According to the study while there is no vaccine Ahsan Ali Siddiqui, [11] current- 
ly available for COVID-19 patients the treatment with Convalescent Plasma with other western medicines saves lives of hundreds of thousands of patients in COVID-19 Pandemic. There is need of more advance research and action to find out the Treatment of COVID-19 Pandemic. Global health including public health preventive medicine has failed the world in this current COVID-19 Pandemic when more than Quarter million people Ahsan Ali Siddiqui, [11] died all around the world and approximately 4.2 Million people suffered from this deadly COVID-19 Pandemic (Figure 5). After seeing the Disaster resulting from COVID-19 Pandemic Ahsan Ali Siddiqui, [12] in last five months all over the world, where almost 370,000 people died and approximately 6 Million people are sick due to COVID-19. There is urgent need of VACCINE of COVID-19 Pandemic and there is news that may be Vaccine could be available in December 2020 or later. The lesson learned is that we in Twenty first century do not have capability to develop immediate Medicines or Vaccines for new disease. Medical Ahsan Ali Siddiqui, [12] Scientists need to study more and Medical Science need more hard work to learn the diseases and their urgent treatment.

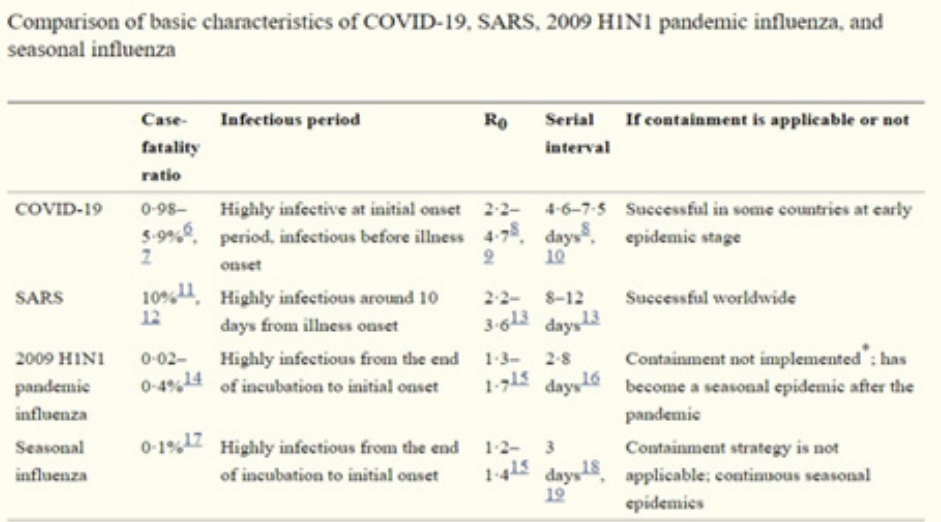

Figure 3: Data show that COVID-19 is more severe an illness than is seasonal influenza and SARS-CoV-2 is more contagious than are seasonal influenza viruses having a basic reproduction number ( $\mathrm{R}$ 0) nearly twice as high. Zhongjie Li, et al. [9].

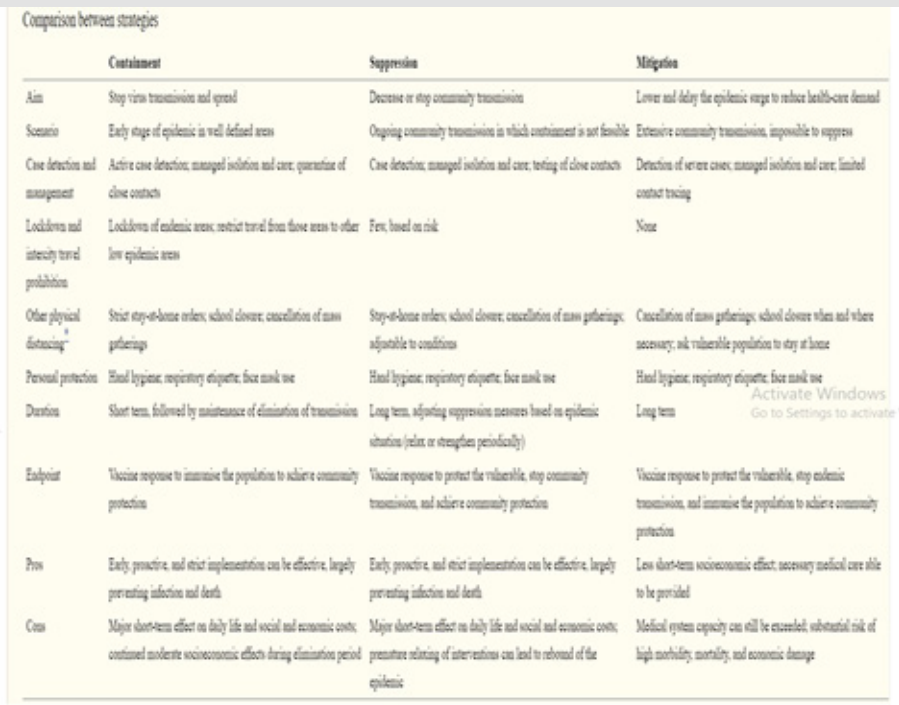

Figure 4: Zhongjie Li, et al. [9]..

\section{Methods}

The Author of this Article has done Literature Review, Comparison and Critical analysis of more than 25 Published Articles and other reviews. Author has chosen the Comparative Literature review as methodology for this research article. The purpose is to show that Randomly chosen articles are in favor of "Is COVID-19 Pandemic is out of control as compare to other Medical and Surgical Diseases, where Proven treatment is available for ill Patients". SPSS 19 software is used to show Diagrammatic presentation for the results and analysis. Initial part of the Article discusses and refer- 
enced the epidemiology and prevention of COVID-19 Pandemic. In the last part of the article the author discusses the other Medical/ surgical diseases and treatment and preventions (Table 3). Current Pandemic of COVID-19 Ahsan Ali Siddiqui, [13] has taught all the Global Health authorities such as WHO, UN, UNESCO, UNICEF, UNHCR, EU Others and all Governments of 200 countries that we were not ready for COVID-19. Although Developed Countries such as USA, UK, France and countries of EU spends Billions of US Dollars on their Health System but it did not stop the Deaths of COVID-19 Pandemic in their countries and they are actually affected the most in this world.
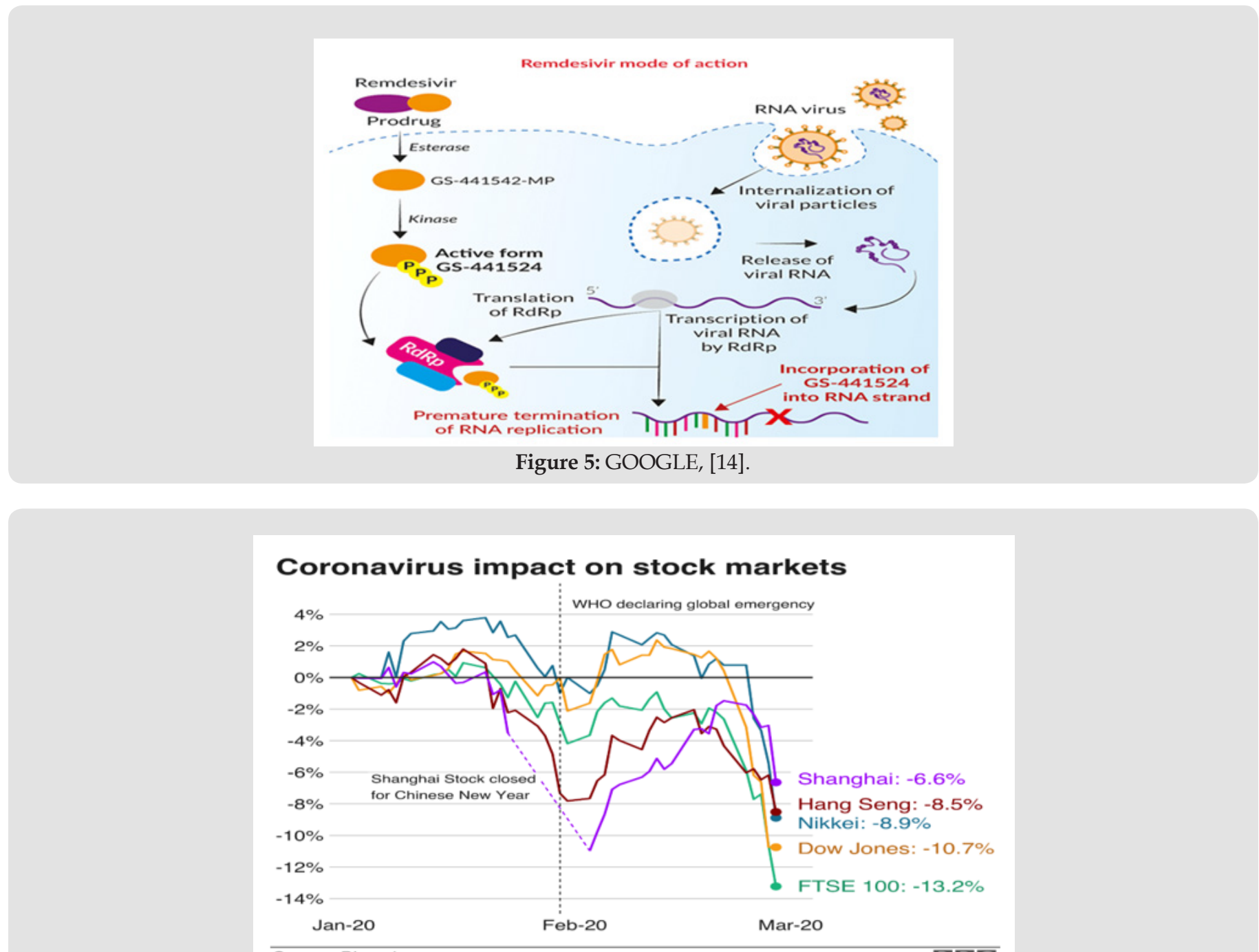

Figure 6: GOOGLE, [15].

Table 3: 15 Selected Articles to show that is COVID-19 Pandemic is out of control as compare to other Medical and Surgical Diseases where Proven treatment is available for ill Patients.

\begin{tabular}{|c|c|c|c|c|}
\hline S.NO & $\begin{array}{l}\text { Complete Reference of the Arti- } \\
\text { cles selected for study }\end{array}$ & $\begin{array}{l}\text { Study favors "is COVID-19 } \\
\text { Pandemic is out of control as } \\
\text { compare to other Medical and } \\
\text { Surgical Diseases where Proven } \\
\text { treatment is available for ill } \\
\text { Patients" - YES }\end{array}$ & $\begin{array}{l}\text { Study ignores "is COVID-19 } \\
\text { Pandemic is out of control } \\
\text { as compare to other Medical } \\
\text { and Surgical Diseases where } \\
\text { Proven treatment is avail- } \\
\text { able for ill Patients" - No }\end{array}$ & $\begin{array}{l}\text { Percentages } \% \text { of Articles } \\
\text { agreed "is COVID-19 Pandemic } \\
\text { is out of control as compare to } \\
\text { other Medical and Surgical Dis- } \\
\text { eases where Proven treatment } \\
\text { is available for ill Patients" }\end{array}$ \\
\hline 1 & $\begin{array}{l}\text { Yunjun Zhang, Yuying Li, Lu Wang, } \\
\text { Mingyuan Li et al. (2020) Evalu- } \\
\text { ating Transmission Heterogeneity } \\
\text { and Super-Spreading Event of } \\
\text { COVID-19 in a Metropolis of China. } \\
\text { Int J Environ Res Public Health. } \\
\text { 2020 May; 17(10): 3705. doi: } \\
\text { 10.3390/ijerph17103705. }\end{array}$ & YES & ------ & $100 \%$ \\
\hline
\end{tabular}




\begin{tabular}{|c|c|c|c|c|}
\hline 2 & $\begin{array}{l}\text { Zhongjie Li, Qiulan Chen, Luzhao } \\
\text { Feng, Lance R et al. (2020) Active } \\
\text { case finding with case manage- } \\
\text { ment: the key to tackling the } \\
\text { COVID-19 pandemic. Lancet. } 2020 \\
\text { 4-10 July; 396(10243): 63-70. doi: } \\
\text { 10.1016/S0140-6736(20)31278-2. }\end{array}$ & YES & ------ & $100 \%$ \\
\hline 3 & $\begin{array}{l}\text { Ahsan Ali Siddiqui (2020) The Use } \\
\text { of Latest Medical Technology and } \\
\text { Taking Benefits from Technology } \\
\text { to Treat Various Medical Diseases } \\
\text { Including Covid-19 in the Current } \\
\text { Pandemic. } 2020 \text { - 2(3) OAJBS. } \\
\text { ID.000185. DOI: } 10.38125 / 0 A- \\
\text { JBS.000185. }\end{array}$ & YES & ------ & $100 \%$ \\
\hline 4 & $\begin{array}{l}\text { Ahsan Ali Siddiqui. (2020) The } \\
\text { Need of Early Detection of Positive } \\
\text { COVID-19 Patients in the Communi- } \\
\text { ty by Viral Tests (e.g. RTPCR Tests) } \\
\text { and Antibody Tests (Serological } \\
\text { Tests) to Stop the Spread. 2020 - } \\
\text { 9(1). AJBSR.MS.ID.001357. DOI: } \\
\text { 10.34297/AJBSR.2020.09.001357. }\end{array}$ & YES & ------ & $100 \%$ \\
\hline 5 & $\begin{array}{c}\text { Ahsan Ali Siddiqui. (2020) Ad- } \\
\text { vancement in Medical Sciences to } \\
\text { Treat Medical and Surgical Diseases } \\
\text { including Prevention, Treatment } \\
\text { and Vaccine Development of } \\
\text { COVID-19 in Pandemic. Biomed J } \\
\text { Sci \& Tech Res 28(4)-2020. BJSTR. } \\
\text { MS.ID.004695. }\end{array}$ & YES & ------ & $100 \%$ \\
\hline 6 & $\begin{array}{l}\text { Ahsan Ali Siddiqui (2020) } \\
\text { COVID-19 Pandemic and Public } \\
\text { health Preventions to Reduce the } \\
\text { Infection, Incidence and Distri- } \\
\text { bution among the Community. } \\
2020 \text { - 2(2) OAJBS.ID.000178. DOI: } \\
\text { 10.38125/OAJBS.000178. }\end{array}$ & YES & ------ & $100 \%$ \\
\hline 7 & $\begin{array}{l}\text { Ahsan Ali Siddiqui. (2020) Covid-19 } \\
\text { Proposed Treatment and other } \\
\text { Medical Diseases Prevention and } \\
\text { Treatment as Modern Medical } \\
\text { Sciences is Beneficial for All of Us. } \\
\text { Biomed J Sci \& Tech Res 28(4)- } \\
\text { 2020. BJSTR. MS.ID.004696. }\end{array}$ & YES & ------ & $100 \%$ \\
\hline 8 & $\begin{array}{l}\text { Ahsan Ali Siddiqui. (2020) The } \\
\text { Epidemiology of COVID-19 Novel } \\
\text { Corona Virus in Incidence and the } \\
\text { Distribution of the Disease across } \\
\text { the World. } 2020 \text { - } 9(4) \text {. AJBSR. } \\
\text { MS.ID.001407. DOI: } 10.34297 / \\
\text { AJBSR.2020.09.001407. }\end{array}$ & YES & ------ & $100 \%$ \\
\hline 9 & $\begin{array}{l}\text { Ahsan Ali Siddiqui. (2020) Role of } \\
\text { Convalescent Plasma Therapy in } \\
\text { Successful Prevention and Treat- } \\
\text { ment of Covid-19 Novel Corona Vi- } \\
\text { rus Critical Patients, In } 2020 \text { Global } \\
\text { Pandemic. Biomed J Sci \& Tech Res } \\
\text { 28(2)-2020. BJSTR. MS.ID.004618. }\end{array}$ & YES & ------- & $100 \%$ \\
\hline 10 & $\begin{array}{c}\text { Jamali Z, Siddiqui Ahsan, Jamali D, } \\
\text { Nazim S, et al. (2018) Correlation } \\
\text { of Early and Late Cord Clamping } \\
\text { Time with Hematological Variables: } \\
\text { An Observation Study Focusing } \\
\text { on The Neonatal Outcomes. SOJ } \\
\text { Gynecology Obstetric Women's } \\
\text { Health 4(1): 1-5. DOI: http:// } \\
\text { dx.doi.org/10.15226/2381- } \\
\text { 2915/4/1/00135. }\end{array}$ & YES & ------ & $100 \%$ \\
\hline
\end{tabular}




\begin{tabular}{|c|c|c|c|c|}
\hline 11 & $\begin{array}{c}\text { Jamali Z, Fatima M, Yaqoob S, } \\
\text { Ahsan S, et al. (2018) Neonatal } \\
\text { Outcomes in Cord Clamping; An } \\
\text { Observational Study Highlighting } \\
\text { the Correlation of Cord Clamping } \\
\text { Time with Hematological Param- } \\
\text { eters. SOJ Gynecology Obstetric } \\
\text { Women's Health 4(1): 1-5. DOI: } \\
\text { http://dx.doi.org/10.15226/2381- } \\
\text { 2915/4/1/00134. }\end{array}$ & YES & ------- & $100 \%$ \\
\hline 12 & $\begin{array}{c}\text { Amna MB, Siddiqui AA, Wajid Z, et } \\
\text { al. (2018) Presentations in Patients } \\
\text { of Chronic Myeloid Leukemia; an } \\
\text { Observational Study Focusing on } \\
\text { the Association of Hematological } \\
\text { Parameter on Gender. Cancer Sci } \\
\text { Res Open Access 5(1): } 1-5 \text {. DOI: } \\
\text { http://dx.doi. org/10.15226/cs- } \\
\text { roa.2017.00139. }\end{array}$ & YES & ------- & $100 \%$ \\
\hline 13 & $\begin{array}{c}\text { Reena Kumari, Ali Siddiqui A, } \\
\text { Zubair T, Fatima S, et al. (2018) Lev- } \\
\text { els of electrolyte in cancer patients } \\
\text { a prospective study focusing on the } \\
\text { Variations before and after therapy. } \\
\text { Palliative Med Care } 5(4): 1-4 \text {. DOI: } \\
\text { http://dx.doi.org/10.15226/2374- } \\
\text { 8362/5/4/00168. }\end{array}$ & YES & ------- & $100 \%$ \\
\hline 14 & $\begin{array}{c}\text { Reena P, Ali J, Ahsan Ali S, Nasir M, } \\
\text { et al. (2018) Febrile Neutropenia in } \\
\text { Patients Receiving Chemotherapy; } \\
\text { an observational study highlighting } \\
\text { its association with hematological } \\
\text { parameters on gender basis. Cancer } \\
\text { Sci Res Open Access 5(1): } 1-5 \text {. DOI: } \\
\text { http://dx.doi.org/10.15226/cs- } \\
\text { roa.2017.00140. }\end{array}$ & YES & ------- & $100 \%$ \\
\hline 15 & $\begin{array}{c}\text { Amna MB, Ahsan Ali S, Shahzain H, } \\
\text { Mir A, et al. (2018) Characteristics } \\
\text { of chronic myeloid leukemia: an } \\
\text { observational study highlight- } \\
\text { ing the correlation of age with } \\
\text { hematological parameters. Cancer } \\
\text { Sci Res Open Access 5(1): 1-4. DOI: } \\
\text { http://dx.doi. org/10.15226/cs- } \\
\text { roa.2017.00142. }\end{array}$ & YES & ------- & $100 \%$ \\
\hline
\end{tabular}

The reason is, there is no current Vaccine, proven Treatment for COVID-19 to this date and still research is going on to find the right Treatment or Vaccine for COVID-19 [14-16]. More hard work needed in Medical Ahsan Ali Siddiqui, [13] Sciences to find out the Proven and approved vaccine and treatment for current pandemic or for preparation for Future Epidemics (Figure 6).

\section{Results}

Author of this Article has used SPSS 19 Software to present the results. First SPSS Diagram shows that All selected 15 Articles favors "Is COVID-19 Pandemic is out of control as compare to other Medical and Surgical Diseases, where Proven treatment is available for ill Patients". The Second SPSS Diagram shows that 15 Articles agreed $100 \%$ for "Is COVID-19 Pandemic is out of control as compare to other Medical and Surgical Diseases, where Proven treatment is available for ill Patients". The main theme of this Article Ahsan Ali Siddiqui, [17] is to discuss the Preventions, training, and control strategies against COVID-19 novel corona virus in China in initial first two months of Pandemic. When Chinese health authorities in Wuhan china found Novel coronavirus pneumonia (NCP) in patients in health facilities they first treated them with (TCM) Traditional Chinese medicines with western medicines. In most of the cases they have found (TCM) Traditional Chinese medicines more effective than other medicines. The current positive statistics of Pandemics about China shows the complete control on COVID-19 with no spread and no Fatalities in May 2019. While the Pandemic of Ahsan Ali Siddiqui, [17] COVID-19 is on the rise all around the world specially in the USA, Europe, and the UK.

You can reduce your chances Ahsan Ali Siddiqui, [18] of being infected World Health Organization or spreading COVID-19 by taking some simple precautions such as Regularly and thoroughly clean your hands with an alcohol-based hand rub or wash them with soap and water. Current Pandemic of COVID-19 has taught us that we in the twenty first century is not ready to provide health care to vulnerable community such as elders, children, and sick people with chronic illness. Such vulnerable people with bad health 
and low socio-economic status are more prone to get effected by COVID-19 novel corona virus. More serious work needed Ahsan Ali Siddiqui, [18] to be done by Global health agencies and world organizations such as WHO, CDC, UN, UNESCO, UNHCR others. This Article teaches us the lesson Ahsan Ali Siddiqui, [19] that Technology in Medical Sciences and Inventions, Discovery of new Medicines and Surgical Instruments are Blessings for Mankind. Latest Technologies such as MRI Scans, CT Scans, Chemotherapy, Radiotherapy, Nu- clear Technology, X rays/ Ultrasound, Latest Laparoscopic surgery, Endoscopy, Angioplasty others are treating more ill patients than ever before.

But more Medical research is needed to find the Treatment for COVID-19 Pandemic, Ebola, MERS, Avian Influenza, Swine Flu and other Viral diseases. Urgent research institutes needed to build up for the discovery of new Vaccines when needed in times of Ahsan Ali Siddiqui, [19] COVID-19 Pandemic.

\section{Discussion}

\section{Discussion About Other Medical and Surgical Diseases and Their Treatment}

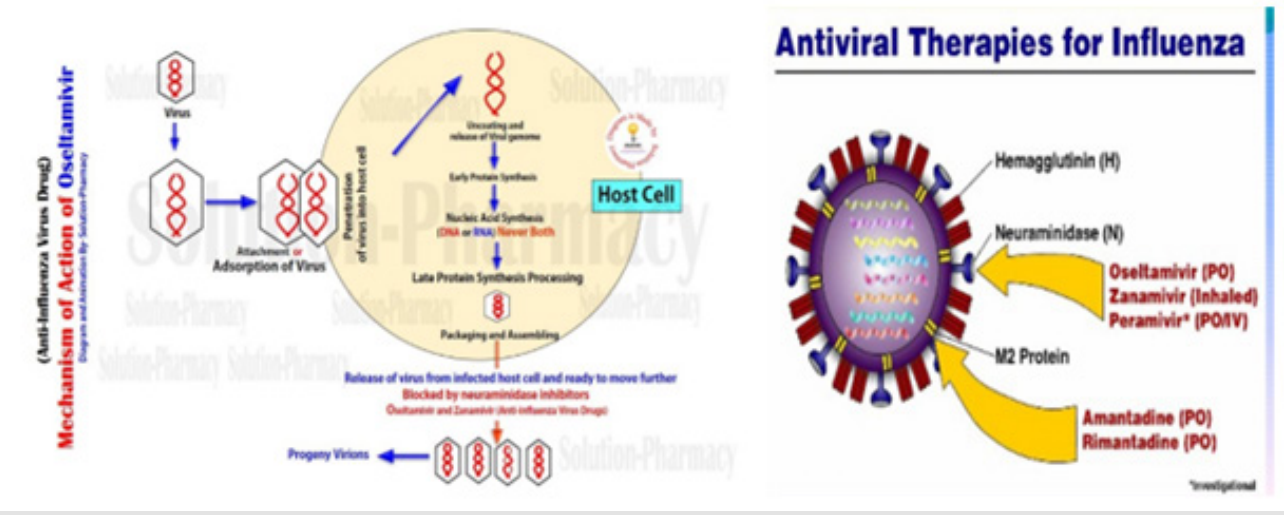

Figure 7: GOOGLE [22].

Type 1 diabetes mellitus-T1DM is a condition Andrej Janež, et al. [20] in which the body can no longer produce sufficient amounts of its own insulin. As a result, blood sugar (glucose) levels increase and in the absence of supplemental insulin diabetic coma and death will eventually occur. In order to meet the standard treatment target (glycated hemoglobin levels $<7 \%$ ), patients with T1DM require insulin supplementation which is given as injections at set times of the day (basal) and at mealtimes bolus or prandial. Patients may use a pump that provides a continuous supply of insulin Andrej Janež, et al. [20] if they do not meet treatment targets or if they have frequent or severe hypoglycemia. Avian flu- H5N1 is a type of influenza A Ahsan Ali S, [21] that mainly infects birds but occasionally affects humans. Avian flu can be transmitted from live birds to people although transmission between humans is very inefficient. Wild birds are the natural hosts of the virus hence the name avian influenza or bird flu. The author told the dangers and the harmful effects done by the Avian flu and how this deadly disease spread in the communities silently. And the health departments come to know about this disease when it done its work killing the innocent people Ahsan Ali S [21,22] terrorize the whole community by its deadly results (Figure 7).

The purpose of this study was to Jamali Z, et al. [23] evaluate the neonatal outcomes in early and delayed cord clamping and to find their correlation in early and delayed cord clamping with different hematological parameters in neonates. The present study predicted that no correlation in either group existed between hemoglobin he- matocrit and bilirubin with increasing cord clamping time. A total of 342 pregnant Jamali Z, et al. [24] females in their third stage of labor were selected for this study. No correlation existed between hemoglobin and hematocrit with cord clamping time ( $p$-value 0.661 ) and ( $p$-value 0.439 ) respectively. Weak positive correlation ( $p=0.002, r=0.169$ ) existed between bilirubin levels with clamping time. Chronic Myeloid Leukemia-CML Amna MB, et al. [25] is malignancy of blood that arise from a molecular alteration in a solitary pluripotent hematopoietic stem cells resulting in continuous production of the myeloid progeny. In $90 \%$ of cases CML is caused due to the existence of Philadelphia chromosome and infrequently by Hyper diploidy of greater than 50 chromosomes. The present study predicted that considerable difference did not exist in various hematological parameters of male and female CML patients. However, there was significant difference Amna MB, et al. [25] observed in myelocyte count of these patients on the basis of gender.

Cancer patients are usually encountered Reena Kumari, et al. [26] by number of different issues one of them include electrolyte imbalance. Other causes of electrolyte imbalance include para neoplastic syndrome or those associated with chemotherapeutic regimes. Life threatening complication has been documented because of these malignant specific electrolyte disorders they may require urgent therapy and correction. Our study Reena P, et al. [27] showed that among male and female cancer patients on chemotherapy, more than half of males were found to have febrile neutropenia, while fewer females had febrile neutropenia. There was no 
significant difference in occurrence of febrile neutropenia between two genders. In $90 \%$ of cases, CML is because of the Amna MB, et al. [28] presence of Philadelphia chromosome and uncommonly by Hyperdiploidy of $>50$ chromosomes. Expansion of break point cluster region and Abelson's (BCR-ABL) a new fusion gene due to the translocation between chromosome 9 and 22 t $(9,22)$ (q34; q11) encodes for an oncoprotein (P210) located in the cytoplasm that has a strong capability to stimulate tyrosine kinase. Resulting in activation of several signals that alter hematopoietic stem cells into the leukemic cells, as a result amplifying tyrosine kinase action which plays a fundamental role in the pathogenesis of CML.

This study predicted that there is difference in electrolyte levels before and after chemotherapy in cancer patients. Furthermore Reena Kumari, et al. [29] no correlation was observed in various electrolytes with the duration of chemotherapy although the difference in electrolyte levels is not clinically significant and can be managed promptly in less time.

\section{Conclusion}

Although the Incidence, Distribution, Illness, and mortality due to COVID-19 Pandemic is reducing day by day as compare to peak in March 2020 in the EU, the UK and the USA. But the Head of CDC USA warn the WHO and US Government that COVID-19 Pandemic has the tendency to become deadly as same as Spanish flu Pandemic in 1918 where approximately 60 to 100 million people died. The governments of the 200 affected countries due to COVID-19 should understand the seriousness of the warnings and do the recommended preventions such as wearing Masks, washing hands with soap or sanitize it with Alcohol, social distancing and staying home as much as possible. In case of fever and shortness of breath take oxygen therapy, and paracetamol and ask the doctor for Antiviral, Plasma therapy and dexamethasone others as soon as possible.

\section{References}

1. Carlyn Harris, Gail Carson, J Baillie, Peter H, Harish Nair, et al. (2020) An evidence-based framework for priority clinical research questions for COVID-19. J Glob Health 10(1): 011001.

2. Ahsan Ali Siddiqui (2020) The Use of Latest Medical Technology and Taking Benefits from Technology to Treat Various Medical Diseases Including Covid-19 in the Current Pandemic 2(3).

3. Jieyun Zhu, Zhimei Zhong, Hongyuan Li, Pan Ji, Jielong Pang, et al. (2020) CT imaging features of 4121 patients with COVID-19: A metaanalysis. J Med Virol 92(7): 891-902.

4. Ahsan Ali Siddiqui (2020) The Need of Early Detection of Positive COVID-19 Patients in the Community by Viral Tests (e.g. RTPCR Tests) and Antibody Tests (Serological Tests) to Stop the Spread 9(1).

5. Ahsan Ali Siddiqui (2020) Advancement in Medical Sciences to Treat Medical and Surgical Diseases including Prevention, Treatment and Vaccine Development of COVID-19 in Pandemic. Biomed J Sci \& Tech Res 28(4).

6. Yunjun Zhang, Yuying Li, Lu Wang, Mingyuan Li, Xiao-Hua Zhou, et al. (2020) Evaluating Transmission Heterogeneity and Super-Spreading Event of COVID-19 in a Metropolis of China. Int J Environ Res Public Health 17(10): 3705.

7. Ahsan Ali Siddiqui (2020) COVID-19 Pandemic and Public health Pre- ventions to Reduce the Infection, Incidence and Distribution among the Community 2(2).

8. Ahsan Ali Siddiqui (2020) Covid-19 Proposed Treatment and other Medical Diseases Prevention and Treatment as Modern Medical Sciences is Beneficial for All of Us. Biomed J Sci \& Tech Res 28(4).

9. Zhongjie Li, Qiulan Chen, Luzhao Feng, Lance R, Yinyin Xia, et al. (2020) Active case finding with case management: The key to tackling the COVID-19 pandemic. Lancet 396(10243): 63-70.

10. Ahsan Ali Siddiqui (2020) The Epidemiology of COVID-19 Novel Corona Virus in Incidence and the Distribution of the Disease across the World 9(4).

11. Ahsan Ali Siddiqui (2020) Role of Convalescent Plasma Therapy in Successful Prevention and Treatment of Covid-19 Novel Corona Virus Critical Patients, In 2020 Global Pandemic. Biomed J Sci \& Tech Res 28(2).

12. Ahsan Ali Siddiqui (2020) The Urgent Need of Reliable and Approved Vaccination for COVID-19 Novel Corona Virus in Current Pandemic. Biomed J Sci \& Tech Res 28(2).

13. Ahsan Ali Siddiqui (2020) The Recent Management and Treatment of COVID-19 Novel Corona Virus "Better use of Science, Better Treatment for COVID-19 Patients". 2(3).

14. (2020) GOOGLE remdesivir mechanism of action, IMAGES.

15. (2020) GOOGLE covid-19 economic impact IMAGES.

16. IBM (2006) IBM SPSS Software USA.

17. Ahsan Ali Siddiqui (2020) Covid-19 Novel Corona Virus Control and preventions In China and Discussing Their National Success to Back to Normal Life, While World Is Combatting the Deadly Viral Pandemic. Biomed J Sci \& Tech Res 27(4).

18. Ahsan Ali Siddiqui (2020) The Epidemiology of COVID-19 Novel Corona Virus to Possibly Control the Disease and Other Factors Relating to Health Around the World. 2(2).

19. Ahsan Ali Siddiqui (2020) The Role of Medical Sciences to Save Lives of Mankind from Communicable and Non-Communicable Diseases Including Current COVID-19 Pandemic. 2(3).

20. Andrej Janež, Cristian Guja, Asimina Mitrakou, Nebojsa Lalic, Tsvetalina Tankova, et al (2020) Insulin Therapy in Adults with Type 1 Diabetes Mellitus: A Narrative Review. Diabetes Ther 11(2): 387-409.

21. Ahsan Ali S (2018) The Global Threat of Bird (Avian) Flu its Treatment Methods and Public Health Preventive Measures. SOJ Vet Sci 4(3): 1-4.

22. (2020) GOOGLE oseltamivir mechanism of action.

23. Jamali Z, Siddiqui Ahsan, Jamali D, Nazim S, Shahzain Hasan, et al. (2018) Correlation of Early and Late Cord Clamping Time with Hematological Variables: An Observation Study Focusing on The Neonatal Outcomes. SOJ Gynecology Obstetric Women's Health 4(1): 1-5.

24. Jamali Z, Fatima M, Yaqoob S, Ahsan S, Dara Jamali, et al. (2018) Neonatal Outcomes in Cord Clamping; An Observational Study Highlighting the Correlation of Cord Clamping Time with Hematological Parameters. SOJ Gynecology Obstetric Women's Health 4(1): 1-5.

25. Amna MB, Siddiqui AA, Wajid Z, Aisha Moin, Amsa Khan, et al. (2018) Presentations in Patients of Chronic Myeloid Leukemia; an Observational Study Focusing on the Association of Hematological Parameter on Gender. Cancer Sci Res Open Access 5(1): 1-5.

26. Reena Kumari, Ali Siddiqui A, Zubair T, Fatima S, Atika Shaheer, et al. (2018) Levels of electrolyte in cancer patients a prospective study focusing on the Variations before and after therapy. Palliative Med Care $5(4): 1-4$.

27. Reena P, Ali J, Ahsan Ali S, Nasir M, Samurna Sabir, et al. (2018) Febrile Neutropenia in Patients Receiving Chemotherapy; an observational study highlighting its association with hematological parameters on gender basis. Cancer Sci Res Open Access 5(1): 1-5. 
28. Amna MB, Ahsan Ali S, Shahzain H, Mir A, Mehreen Ibrahim, et al (2018) Characteristics of chronic myeloid leukemia: an observational study highlighting the correlation of age with hematological parameters. Cancer Sci Res Open Access 5(1): 1-4.

ISSN: 2574-1241

DOI: $10.26717 /$ BJSTR.2020.29.004816

Ahsan Siddiqui. Biomed J Sci \& Tech Res

(C) This work is licensed under Creative

Submission Link: https://biomedres.us/submit-manuscript.php
29. Reena Kumari, Ahsan Ali S, Khurram Zia MD, Zubair T, Samahir Imtiaz, et al. (2018) Correlation of Duration of Chemotherapy with Electrolytes in Cancer Patients: A Prospective Study Assessing the Relationship with Various Electrolytes. Cancer Sci Res Open Access 5(2): 1-4.

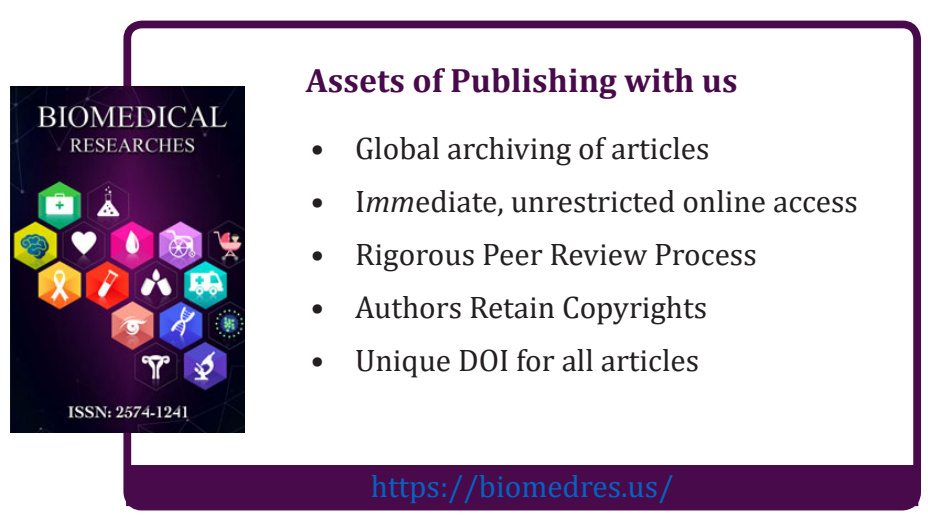

